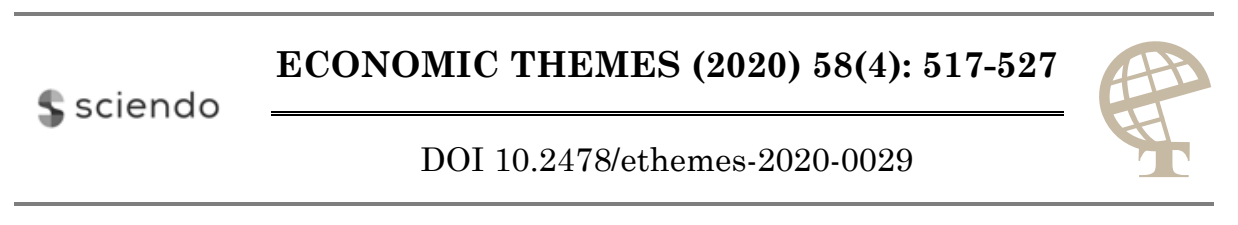

\title{
JUSTIFICATION OF THE USURY CONTRACT IN THE LAW OF THE REPUBLIC OF SERBIA: ADVANTAGES AND DISADVANTAGES
}

\author{
Tanja Praštalo \\ Faculty of Law for Commerce and \\ Judiciary University Business Academy in Novi Sad, Serbia \\ $\bowtie$ tanja.prastalo@pravni-fakultet.info
}

UDC

164.04

Review paper

Received: 26.04.2020 Accepted: 29.09.2020

\begin{abstract}
A usury contract is a null and void contract whereby someone, using the condition of another's misfortune or material hardship, lack of experience, recklessness, or dependency, obtains for himself or for a third party a benefit that is clearly disproportionate to what he or she has given or done in return or committed to give or do. The usury contract violates one of the basic principles of the law of obligations, which is the principle of equality of obligations, in other words, the equality of the value of mutual benefits of the contracting parties. Although the legal definition of the usury contracts (Law on Contracts and Torts, Article 141, paragraph 1) is comprehensive enough, it is not easy for the courts to decide whether one contract is usury or not, i.e. null and void. The subject of this paper is the analysis of the usury contracts through the current case law in the context of the justification of the existence of this institute in the legislation of Serbia, having in mind the division of opinions, and because as much as a party using a person's difficult material situation is presented in a negative context, the contract of this type is nonetheless a product of the willing action of both parties. The topic of this paper is very sensitive and requires a reasoned methodological approach and analysis. The aim of the paper is also to encourage the affected party in the usury contract to enter into litigation to protect their rights.
\end{abstract}

Keywords: usury contract, case law, justification of the usury contract in the legislation of the Republic of Serbia, advantages and disadvantages of the usury contract, abuse of the usury contract, overcoming usury contract shortcomings.

JEL classification: K11 


\section{Introduction}

Usury contracts have existed since ancient times. It is also known as a loan shark agreement, named after a loan shark, or a person who gives out loans with excessive interest. The term "usury contract" was first used when rich merchants would give out cash loans to farmers, and who would buy their farm products at lower prices as security, taking advantage of their difficult material situation. The usury contract was once regulated by the Serbian Civil Code, but not in the prohibited and null and void provisions of the law. Up to $12 \%$ interest was allowed. If the contract contained a provision that required interest over the above amount, such a contract would be null and void. The law protects the constitutionally established order, and, therefore, the Law on Contracts and Torts provides for the nullity of contracts that are contrary to the constitutional order (Bikić 2007, p. 177).

The usury contract is contrary to imperative norms, public order, morals, and good customs. As the existence of this type of contract requires that objective and subjective conditions to be cumulatively fulfilled, it is a much more onerous task for the court to assess and determine the propriety of this contract than to determine its opposition to imperative norms. Morality and moral understanding are variable categories. (Bikić, op.cit.) It is also necessary to prove that the contracting party was aware that it was taking advantage of a difficult material situation to obtain a benefit for themselves or a third party, which further complicates court rulings.

It is because of this sensitivity, but also in order not to lightly void already concluded contracts, Serbian legislation in Article 141 paragraph 3 of the Law on Contracts and Torts stipulates that the injured party may file a claim for reduction of the obligation to a fair amount within five years counting from the conclusion of the contract. Here, the question of the justification of the convalidation of the usury contract stands contrary to imperative norms, public order, morals, and good customs. Although a party in a difficult financial situation has tried unsuccessfully to obtain funds from financial organizations registered for granting loans or credits, the issue of that person's conscientiousness is now in question. Revalidation of a contract legally allows a contractually weaker party who willingly and knowingly signed a usury contract to sue the other party to reduce the contracted obligation, thereby obtaining cash, reducing the amount of repayment. Therefore, it is almost as if the party has concluded a loan agreement with a financial registered organization. Due to everything mentioned above and many other issues, the usury contract is an interesting and sensitive institution, but also a great challenge. The paper will try to answer questions and uncertainties that arise from usury contracts, through case law analysis. 


\section{The Definition and Elements of the Usury Contract}

Usury contracts are onerous contracts, that is, contracts where one contracting party owes compensation to the other contracting party for the benefit it derives from the contract. This contract is also referred to as a fee agreement or a one-time contract, and each party appears simultaneously as a creditor and as a debtor (Lejić 2013, p. 77). It follows from the legal definition of the usury contract in question that it is made up of two conditional elements - objective and subjective.

The objective element is easy to recognize since it represents the disproportionate obligations of the contracting parties. A disproportionate obligation does not only have to be about the amount of money, but also about a certain act, omission, or promise, etc. It is not difficult to establish this objective element in case-law, since the disproportion must be obvious, therefore, the obligation of one contracting party drastically deviates from the obligation of the other contracting party. For the assessment of the existence of an apparent disproportion, the turnover value of the mutual obligation at the time of the conclusion of the contract is taken into account (Milošević, 1970, p. 77). Fulfilment of the objective condition violates the basic principle of Obligatory law - the principle of equal value of giving. This principle has been emphasized in the Law on Contracts and Torts as one of the basic principles (Marić, 2015, 889-908). The principle of equal value of giving is the principle according to which in a bilaterally binding contract the obligation of each party should stand in a certain value relating to the obligation of the other party (Perovic, 1995, p. 38).

The subjective condition, as an element of the usury contrac,t provides an answer to the reason why the contract is recognized as usury. It refers to the use of necessity, difficult material situations or the recklessness of the other party to obtain benefits for itself or the third party. The emphasis of the subjective condition is put on the party who knowingly takes advantage of others' misfortune in an immoral, ruthless, and reckless manner.

In addition to the subjective and objective elements, for the contract to be summed up as usury, it is necessary to have an onerous contract, to have a disproportion in the obligations of the contracting parties, and to have the consent of the exploited person due to some difficulty.

The state of necessity in the context of the subjective element of the usury contract is a common material threat to the weaker party, but it does not have to relate only to money. It may be a threat to the life and body of the other party or a person close to the contracting party. The judgment of the Court of Appeal in Novi Sad, file number Gz. 1523/11 of 01/02/2012. states: "The Basic court finds that the defendant worked as a waitress on the L.o.t.s. cruise ship, for the RCCL company based in M. The defendant had previously suffered from discus hernia, but in December 2007, complications arose and the disease progressed, and the 
defendant's leg swelled, she was not allowed to leave the ship, so she was placed in a cabin and treated as a patient until she returned to Serbia, where she continued her treatment. At that time, the plaintiff, who had previously suffered an injury at work, also worked as an assistant waiter and managed to obtain damages in the case against the employer. SW, one of the ship's employees referred the defendant to the plaintiff for advice on how to reimburse her medical expenses during her treatment in Serbia, as well as the right to reimbursement for her sick leave. The plaintiff offered the defendant assistance, which included finding her a lawyer in M. who would help her claim the right to damages, and the plaintiff advised her on how to obtain the right to unpaid wages and medical expenses, which were paid out after some time. For this assistance, the defendant paid the plaintiff $\$ 1,700$, after which the plaintiff instructed her that she could file a complaint against her employer with RCCL. The plaintiff sent the defendant an email contract, which the defendant had to sign for the plaintiff to assist her in obtaining damages. After some time, the defendant signed the contract and sent it to the plaintiff. According to this agreement, the plaintiff recruited an attorney from the CAC firm based in M. to represent the defendant, with whom the plaintiff was in contact repeatedly by email from June 2008 to June 2009. After the trial was completed, the defendant was paid $\$ 25,000$ in damages. After the payment into the defendant's account, the plaintiff requested the defendant to pay him the agreed $30 \%$ of the compensation paid, which the defendant did not want to do, but paid \$ 1,200 to the plaintiff's account. Furthermore, the trial court found that upon returning to Serbia, the defendant was almost immobile and that she needed continued treatment. This required considerable material costs. During her sick leave, the defendant did not receive earnings, but, following the plaintiff's advice, the same was subsequently paid, as well as medical expenses. After the defendant received reimbursement of unpaid wages and medical expenses, she paid the plaintiff $\$ 1,700$ and then paid him $\$ 1,200$ after paying damages, finding it adequate compensation for his assistance. The defendant did not even specify what the assistance consisted of during the proceedings, stating only that it was predominantly contacting the defendant's lawyer in A. in person (via e-mail), without specifying how much these services cost individually. To such a complete and properly established factual situation, with the assessment of the evidence given in terms of Art. 8 of the Law on Civil Procedure, the trial court correctly renders the decision rejecting the claim. If it follows from the factual basis of the claim that a particular contract is burdensome with usury properties, the court is obliged to evaluate the reasons for nullity."

As already stated, the objective and subjective conditions need to be fulfilled for a contract to be considered usury, which the court correctly ruled rejecting the plaintiff's claim in its entirety.

In the present case, the respondent was in a state of emergency, both in the physical and material sense, which she had proved in the proceedings, thereby 
fulfilling the subjective element, while the fulfillment of the objective element was reflected in the disproportion of obligations. The amount of $30 \%$ of the defendant's compensation received is too large in relation to the plaintiff's "assistance" in the context of the mediation of a couple of emails between the lawyer's office and the plaintiff. The defendant paid $\$ 1,700$ and $\$ 1,200$, therefore, a total of $\$ 2,900.00$ to the plaintiff, which is quite acceptable, and for living standard in Serbia more than acceptable.

The plaintiff had he proved that he had higher costs than the exchange of emails, he would have partially succeeded in the proceedings, as he did not prove his expenditures, his claim was rejected. In addition to the subjective elements of necessity and the difficult material situation, the legal definition also states insufficient experience, recklessness or dependence. Insufficient experience of the affected contracting party is related to life experience, but, what is practically more significant, to certain specialized knowledge in various fields of technical and social sciences (Antić, 2008, p. 413). In the present case, the affected counterparty had no experience in the field of claiming damages, moreover, she did not know that she could sue the employer for damages and succeed in the dispute, while the plaintiff succeeded in the dispute with the employer, which is evidence of his experience in the particular situation.

Therefore, inexperience is ignorance which can be both professional ignorance and ignorance as a consequence depending on the age of a person. Recklessness, as the word itself, implies that a particular person reacts recklessly in a given situation. In the case at hand, the plaintiff gave the defendant some hope that she could succeed in the dispute and receive a substantial amount of money, and the defendant quickly agreed to the amount of $30 \%$ of the damages, since she stated that her treatment costs were high and that any amount she received would be helpful for the coverage of medical and living costs.

The last subjective element of the usury contract is dependency. It represents the subordination of one person to another. Considering that the defendant was on board a cruise ship, far away from her home country, and was barred from leaving the ship, since she was sent to the cabin to be treated as a patient and the plaintiff was on board as the Assistant Chief, that is, her boss, the defendant was in a dependent relationship with the plaintiff. More precisely, she was in a subordinate position. The defendant's objective circumstances led to a dependent relationship with a third party, specifically her boss, the plaintiff.

However, the nullity of the contract did not affect the entire contract; The defendant paid the plaintiff a total of $\$ 2,900.00$, thereby nullifying only a contract provision that amounted to $30 \%$ of the damages paid, while the other provisions remained in force.

Although she did not pay the agreed amount of money, the defendant proved correct by paying the amount of money that was justified for the actions taken by 
the plaintiff. It is concluded that only those contracts which are non-enforceable and which have not produced the desired legal consequences from the point of view of legal order are annulled (Radišić, 1979, p. 145).

\section{Judicial Outcomes of the Procedure Regarding the Usury Contract}

Litigation following the conclusion of the usury contracts is a sensitive matter because the court does not make its final decision solely based on the law (an objective element), but also depending on the fulfillment of the subjective element of such a contract, which is subjected to the personal conviction of the court, based on the evidence presented. The court keeps in view the nullity of a contract as his task in line of duty, while it may be claimed by every person that has an interest in the case. (Law on Contracts and Torts, Article 109 paragraph 1).

The law recognizes that every interested person has the right to claim the nullity of a contract. However, under the positive law of Serbia, the scope of nullity is not equal for contracting parties and interested parties with a legal interest. Thus, according to the opinion of the Court of Appeal in Novi Sad ${ }^{1}$, a third interested party cannot claim the nullity of the usury contract because of the deficiency of the will of the contracting party, unless the weaker of the contracting parties has invoked the lack of will herself (subjective condition). Third parties may seek a declaration of nullity of the contract, but the contractual relationship arising out of the nullity is discussed exclusively between the contracting parties and the legal consequences of the nullity of the contract apply only to the contracting parties. (Ibidem, Gž. 3815/12 of 15 November 2012).

To establish nullity of the contract, the active legitimation has a wider circle of possible subjects and it differs from the active legitimation for claiming nullity which affects only the contractors. The question here is why the Serbian legislation permits the nullity of the usury contract to any legally interested person who does not even need to know the weaker contracting party if it does not allow the success of the dispute unless the weaker party invokes the lack of will? By the stated position of the court, the third interested party, at the moment of filing the claim for annulment of the usury contract, was adjudicated a failure in the dispute regardless of the presented evidence, unless the third party is working together with the weaker contracting party, who, in agreement with the plaintiff, subsequently points out that there was a lack of will at the time of the conclusion of the usury contract. This attitude of the court leads to possible manipulation of the proceedings by the parties, in order to exercise and protect their rights, thereby violating the right to a fair trial as guaranteed by the Convention for the Protection of Human Rights and Freedoms (Law on Ratification of the European Convention for the Protection of Human Rights and Fundamental Freedoms). Article $6 \S 1$ of

\footnotetext{
${ }^{1}$ See the judgment of the Court of Appeal in Novi Sad, Gz. 3815/12 dated November 15, 2012
} 
the Convention guarantees the procedural rights of the parties in the civil proceedings. The Convention establishes the rule of law on which a democratic society is based, as well as the unavoidable role of the judiciary in the administration of justice, thus reflecting the common heritage of the Contracting Countries. (Vitkauskas, Dikov, 2017, pp. 11).

In support of the Court of Appeal's view is the fact that civil contracts are by their nature intuitive personae, in other words, contracts have a relative effect, that is, a contractual relationship exists and operates only between the contracting parties. However, as there are exceptions to this rule (in the case of a third party contract, a collective agreement, a real estate lease agreement, and a Paulian lawsuit), this situation should also be classified in this category. The Law on Contracts and Torts stipulates in Article 109 paragraph 1 that "The court shall keep in view the nullity as his task in line of duty, while it may be claimed by every person interested". Thus, no paragraph of the article of the law stipulates the right to emphasize the nullity of the contract, because the usury contract is contrary to the established and recognized values of the public order of Serbia (imperative norms, good customs, and morals). The law does not even state that an interested party must have a legal interest.

In support of the opinion that such a position of the court is unfair, maybe even shortsighted is the fact that the law stipulates that the court should take nullity into account ex officio. Therefore, even if we accept the court's position that a third interested party cannot invoke the nullity of the usury contract, due to the lack of will of the contracting party, unless the weaker party also invokes lack of will, although, the usury contract can be ex officio annulled by the court (from the reasoning of the Judgment of the Court of Appeal in Novi Sad, business number Gz. 1523/11 of 01.02.2012: "If the factual basis of the claim implies that a particular contract is burdened by usury properties, the court is obliged to evaluate the reasons for nullity").

From all of the above, it can be concluded that such a situation should be classified as an exception to the rule that contractual relations produce legal effect only between the contracting parties.

Article 220 of the Civil Procedure Law provides that a party is obliged to present the facts and produce the evidence on which it bases its claim or which challenges the allegations and evidence of the opposing party. In this context, it is interesting to look at the Judgment of the Court of Appeal in Belgrade, file number Gz. 335/18 from March 22 $2^{\text {nd }}, 2018$, states that "the respondent's complaint which alleges that he was forced to sign loan agreements amounting to $€ 2,500$ each to receive a much smaller amount of money as part of the loan and that the mentioned loan agreements fall under the usury contract definition, the Court of Appeal found unfounded." 
In this particular case, the plaintiff did not prove by any means that at the time of the conclusion of the contract he was in a state of emergency or a difficult material situation, and the allegations he made during the proceedings and in the complaint that he badly needed money were not in themselves sufficient to establish the condition of the defendant's emergency. Further, the plaintiff alleges that the trial court misjudged his testimony and wrongly concluded that he did not know what was written in the contracts, noting that he knew that he had signed contracts amounting to $€ 2,500.00$ each, but that he was compelled to sign them. These allegations were not enough to influence a different decision in this dispute. Specifically, the fact that the Basic court erroneously paraphrased the plaintiff's testimony in the part of the assessment of the parties' statements, stating that the plaintiff did not know what was written in the contracts and still held that the plaintiff's statement in that part was false, although the plaintiff indicated at all times that he knew what he was signing, but that he was under duress, did not affect the court's decision.

Bearing in mind everything stated so far, for the contract to be considered usury, it is necessary to fulfill both the objective and subjective elements that the plaintiff must prove in the proceedings. Therefore, if the party is merely claiming that a contract is usury stating as the reason that the other side needed money and used the situations to get said funds will not make it probable that there was a case of disproportionate obligations and that the "weaker side" was in a state of emergency, thus the fulfillment of the subjective element of the usury contract is missing. Before going to trial to determine whether a contract is usury, the party must substantiate its allegations by covering simultaneously both of the conditional elements of the usury contract prescribed by law. and as stated so far, for a contract to be considered usury, it is necessary to fulfill the objective and subjective conditions which the plaintiff must prove in the proceedings.

\section{Conclusion}

Keeping in mind everything mentioned above, it can be concluded that the usury contract is a very specific type of contract. Its interpretation seems simple at first, but looking through the prism of the Serbian legal system and case law many controversial questions can be raised. There is a reason why Serbian law forbids usury contracts where the exploitation of a state of emergency or a difficult material condition of another person, or his lack of experience, recklessness, or dependency, leads to gained benefits for the other contracting party or a third party. The emphasis is placed on exploiting and outsmarting a party which is in a hopeless situation and which would not have, under other circumstances, concluded such a contract. 
The fact that the law allows for the validation of such a contract is contradictory to the definition of null and void contracts and the fact that the expiration of the nullity of the contract does not have a statute of limitations, thus emphasizing the degree of danger such contracts can have for the society. This is because, probably, the party pointing out that the contract is usury, has unsuccessfully tried to take a loan or credit from the registered financial institutions, and the convalidation of such a contract, keeping in mind everything that was said about usury contracts, makes it possible to manipulate the legal process. With such an attitude, each party of the contract could primarily agree to the usury contract and then sue the other party for the reduction of the obligation because the other party used the state of necessity to gain benefits, and made such a contract socially and legally acceptable, but solely for its own benefit. If the contract is void, therefore contrary to imperative norms, public order, good customs, and morals, then such a contract should not produce any effects.

It is immoral and unscrupulous to further burden the stronger contracting party, if it loses the civil case, under the provisions of the Civil Procedure Law, the losing party shall bear the costs of the proceedings as a whole. In this way, the weaker contracting party has to pay less than initially contracted, and does not bear the costs of the civil procedure if it proves that the contract in question is usury. However, if the validation of the null and void contracts within 5 (five) years is accepted, it should be accepted as an exception that the costs of the proceedings have to be paid by the party invoking these rules, in whole or in part, thus reducing potential abuse and manipulation of the legal system.

Even though each contract is created by the consent of the declared wills of the contracting parties and applied intuitu personae, the existence of the usury contract in Serbian law is justified, although its existence is in opposition to established values in public policy, which are guaranteed by the Constitution, as the highest legal act of the state.

Determining the existence of the subjective element of the usury contract is a burdensome task for the courts, but not impossible. Although the court is bound by the plaintiff's claim, it may nullify any contract that fulfills cumulatively objective and subjective conditions that constitute usury contracts, both during and outside the civil proceedings. The law stipulates that any interested person can invoke nullity without meeting any additional conditions, thus encouraging the removal of such problematic contracts from the legal system. It is precisely because of the subjective and objective conditions that make the contract Usury, which include greed for the benefit of the stronger party, and the difficult situation of the weaker party, the law does not specify which interested parties can invoke nullity, realizing the possibility that any person can do so.

In support of the above mentioned, is the fact that the court, as an independent and impartial body, takes due care of the nullity of the contract. The legislator, if he 
wanted to condition which interested persons have the right to invoke the nullity of the contract, would not have used the word to "anyone" in front of the interested person and would not have the courts watch for the nullity of contracts ex officio. A second-instance authority should be established whose responsibility would be to control and verify contracts of a suspicious nature, immediately after certification by the competent authorities. This would subject the mentioned contracts to a review process lead by competent authorities, thereby reducing the burden on courts to deal with these cases.

\section{References}

Antić, O. (2008). Obligaciono pravo - drugo izmenjeno i dopunjeno izdanje. Pravni , Univerzitet u Beogradu, JP „Službeni glasnik““

Bikić, A. (2007). Obligaciono pravo - opći dio - drugo izmenjeno i dopunjeno izdanje. Pravni fakultet Univerziteta u Sarajevu.

Radišić, J. (1979).Obligaciono pravo - opšti deo. Nolit Beograd

Lejić, G. (2013). Godišnjak studenata, Pravni fakultet Univerziteta u Istočnom Sarajevu, UDC 347.440 .22

Marić, D. Z. (2015). Načelo ekvivalentnosti i prekomerno oštećenje u ugovornom pravu. Zbornik radova Pravnog fakulteta, Novi Sad, 49(2), 889-908.

Milošević, Lj. (1970). Obligaciono pravo, Naučna knjiga, Beograd

Perović, S. (1995). Komentar zakona o obligacionim odnosima, Savremena administracija, Beograd

Vitkauskas, V., Dikov, G. (2017). Zaštita prava na pravično suđenje po Evropskoj konvenciji o ljudskim pravima - Priručnik za pravnike praktičare. Savet Evrope, Beograd

Law on Contracts and Torts ("Official Gazette of the SFRY", No. 29/78, 39/85, 45/89 decision of the USJ and 57/89, "Official Gazette of the FRY", No. 31 / 93, "Official Gazette of SCG", No. 1/2003 - Constitutional Charter and "Official Gazette of RS", No. 18/2020)

Law on Civil Procedure ("Official Gazette of RS", No. 72/2011, 49/2013 - US decision, 74/2013 - US decision, 55/2014, 87/2018 and 18/2020)

Law on Ratification of the European Convention for the Protection of Human Rights and Fundamental Freedoms ("Official Gazette of SCG - International Treaties ", Nos. 9/2003, 5/2005 and 7/2005 - ed. and" Official Gazette of the RS - International Treaties ", Nos. 12/2010 and 10/2015) 12. Law on Ratification of the European Convention for the Protection of Human Rights and Fundamental Freedoms ("Official Gazette of SCG - International Treaties", Nos. 9/2003, 5/2005 and 7/2005 - ed. And "Official Gazette of the RS - International Treaties", Nos. 12/2010 and 10/2015)

Judgment of the Court of Appeal in Novi Sad, file number 1523/11 of 01/02/2012.

Judgment of the Court of Appeal in Novi Sad, Gz. 3815/12 of 15 November 2012

Judgment of the Court of Appeal in Belgrade, Gz. 335/18 of March 22, 2018 


\title{
OPRAVDANOST POSTOJANJA ZELENAŠKOG UGOVORA U PRAVU REPUBLIKE SRBIJE: PREDNOSTI I NEDOSTACI
}

\begin{abstract}
Apstrakt: Zelenaški ugovor je ništav ugovor kojim neko, koristeći se stanjem nužde ili teškim materijalnim stanjem drugog, njegovim nedovoljnim iskustvom, lakomislenošću ili zavisnošću, ugovori za sebe ili za nekog trećeg korist koja je u očiglednoj nesrazmeri sa onim što je on drugom dao ili učinio, ili se obavezao dati ili učiniti. Zelenaškim ugovorima se povređuje jedno od osnovnih načela obligacionog prava, a to je načelo jednakosti prestacija, odnosno jednakosti vrednosti uzajamnih davanja ugovornih strana. Iako je zakonska definicija zelenaškog ugovora precizna, ipak sudovima nije jednostavno presuditi da li je jedan ugovor zelenaški ili ne, odnosno da li je ništav. Predmet rada je analiza zelenaškog ugovora kroz aktuelnu sudsku praksu u kontekstu opravdanosti postojanja ovog instituta u zakonodavstvu Srbije imajući u vidu podeljenja mišljenja, a iz razloga što koliko god strana koja koristi tešku materijalnu situaciju nekog lica bude predstavljena u negativnom kontekstu, ipak je zaključivanje ovog tipa ugovora voljna radnja slabije strane. Tematika ovog rada je vrlo osetljiva i zahteva argumentovani metodološki pristup i analizu. Cilj rada je i da kroz studiju slučaja se podstakne pogođena strana u zelenaškim ugovorom da se upusti u sudski spor radi zaštite svojih prava.
\end{abstract}

Ključne reči: zelenaški ugovor, sudska praksa, opravdanost zelenaškog ugovora u zakonodastvu Republike Srbije 